\title{
Microsatellite marker development for the rubber tree (Hevea brasiliensis): characterization and cross-amplification in wild Hevea species
}

\author{
Camila C Mantello ${ }^{1 *}$, Fernando I Suzuki ${ }^{1}$, Livia M Souza', Paulo S Gonçalves ${ }^{2}$ and Anete P Souza ${ }^{1,3^{*}}$
}

\begin{abstract}
Background: The rubber tree (Hevea brasiliensis) is native to the Amazon region and it is the major source of natural rubber in the world. Rubber tree breeding is time-consuming and expensive. However, molecular markers such as microsatellites can reduce the time required for these programs. This study reports new genomic microsatellite markers developed and characterized in $\mathrm{H}$. brasiliensis and the evaluation of their transferability to other Hevea species.

Findings: We constructed di- and trinucleotide-enriched libraries. From these two libraries, 153 primer pairs were designed and initially evaluated using 9 genotypes of $\mathrm{H}$. brasiliensis. A total of 119 primer pairs had a good amplification product, 90 of which were polymorphic. We chose 46 of the polymorphic markers and characterized them in 36 genotypes of H. brasiliensis. The expected and observed heterozygosities ranged from 0.1387 to 0.8629 and 0.0909 to 0.9167 , respectively. The polymorphism information content (PIC) values ranged from 0.097 to 0.8339 , and the mean number of alleles was 6.4 (2-17). These 46 microsatellites were also tested in 6 other Hevea species. The percentage of transferability ranged from $82 \%$ to $87 \%$. Locus duplication was found in $\mathrm{H}$. brasiliensis and also in 5 of other species in which transferability was tested.
\end{abstract}

Conclusions: This study reports new microsatellite markers for $\mathrm{H}$. brasiliensis that can be used for genetic linkage mapping, quantitative trait loci identification and marker- assisted selection. The high percentage of transferability may be useful in the evaluations of genetic variability and to monitor introgression of genetic variability from different Hevea species into breeding programs.

Keywords: Hevea, H. brasiliensis, Microsatellite, Characterization, Transferability

\section{Findings}

Hevea brasiliensis (Willd. ex Adr. de Juss.) Muell. -Arg., native to the Amazon rainforest, is a diploid $(2 n=36$, $x=9$ ), perennial, monoecious and cross-pollinated tree species. It belongs to the genus Hevea and the botanical family Euphorbiaceae.

The genus Hevea comprises 11 inter-crossable species [1,2] ( $H$. benthamiana Muell.- Arg., $H$. brasiliensis, $H$. carmagoana Pires, $H$. camporum Ducke, $H$. guianensis Aubl, $H$. microphylla Ule, $H$. nitida Mart. ex-Muel.-Arg.,

\footnotetext{
* Correspondence: camila.mantello@gmail.com; anetepsouza@gmail.com

${ }^{1}$ Centro de Biologia Molecular e Engenharia Genética (CBMEG) -

Universidade Estadual de Campinas (UNICAMP), Cidade Universitária Zeferino Vaz, CP 6010, CEP 13083-970, Campinas, SP, Brazil

${ }^{3}$ Departamento de Biologia Vegetal, Instituto de Biologia, Universidade Estadual de Campinas (UNICAMP), Cidade Universitária Zeferino Vaz, CP 6109, CEP 13083-970, Campinas, SP, Brazil

Full list of author information is available at the end of the article
}

H. pauciflora (Spruce ex-Benth.) Muell.-Arg., H. rigidifolia (Spruce ex-Benth.) Muell.-Arg., H. spruceana (Benth.) Muell.-Arg. and H. paludosa Ule), which have evolved in the Amazon rainforest over 100,000 years [3].

Of all the species in the genus Hevea, $H$. brasiliensis is the most economically important, because it is the major source of natural rubber worldwide. Natural rubber is important mainly in the tire industry but also in many other sectors because it is flexible, resistant, impermeable to liquids and abrasion resistant [4]. These singular properties make natural rubber both complementary and competitive to synthetic rubber and furthermore superior to it in varied applications. As is the case for many other perennial trees, rubber tree breeding is time-consuming and expensive. An average duration of 20-25 years of field experiments in large areas is generally required to obtain a new cultivar with reasonably low risks [5].

\section{Biomed Central}


Molecular markers, such as amplified fragment length polymorphisms (AFLPs), restriction fragment length polymorphisms (RFLPs), random amplified polymorphic DNA (RAPD), simple sequence repeats (SSRs or microsatellites) and single nucleotide polymorphisms (SNPs), have successively become increasingly important in plant breeding. These markers are efficient tools for the assessment of genetic diversity, the identification of quantitative trait loci (QTLs) and/or gene mapping, variety protection and marker-assisted selection (MAS) [6].

Of these markers, microsatellite markers are considered the most suitable for genetic studies, because they combine co-dominance and high polymorphism with abundance, locus specificity and uniform dispersion in plant genomes. Moreover, microsatellite markers can discriminate closely related individuals [7]. In addition, microsatellite analysis is inexpensive, high reproducible and highly transferable across related species.

Following biochemical markers such as isozymes [8], molecular markers have been developed and used since the middle of 1990's for diversity studies [9,10], genetic mapping [11] and the identification of genetic loci implicated in the expression of agronomic traits in H. brasiliensis [1114]. However, most of the markers used have been isozyme, RAPD, RFLP or AFLP markers.

To date, few studies using genomic microsatellites $[10,15,16]$ or microsatellites from expressed sequence tags (EST-SSRs) have been published [6]. Accordingly, we present the development of genomic microsatellites using dinucleotide- and trinucleotide- enriched libraries, the characterization of these microsatellite markers in multiple accessions of $H$. brasiliensis and test their transferability in six other Hevea species.

\section{Results}

Microsatellite-enriched library analysis

Di- and trinucleotide-enriched libraries were constructed, and the clones from each library were sequenced (576 and 288 clones, respectively).

A total of 291 (50.5\%) clones from the dinucleotideenriched library contained microsatellite sequences. Since dinucleotide probes were used for the library enrichment, these motifs were the most abundant comprising 324 (90.2\%) SSRs followed by 20 tetranucleotide (5.6\%), 12 trinucleotide $(3.3 \%)$ and 3 pentanucleotide $(0.8 \%)$ (Table 1$)$.

In the trinucleotide-enriched library, 62 (21.5\%) clones contained microsatellites sequences. Trinucleotides were the most frequent motif with 45 (72.5\%) SSRs followed by 13 dinucleotide (20.9\%), 9 tetranucleotide (14.5\%) and 3 pentanucleotide $(4.8 \%)$ SSRs (Table 1$)$.

For some sequences, both the dinucleotide- and trinucleotide-enriched libraries had more than one microsatellite, which explains the greater number of SSRs found compared to the number of sequences analyzed.

A total of 130 and 32 primer pairs were designed based on the di- and trinucleotide-enriched libraries, respectively. To remove possible redundancies with published SSRs, each sequence containing SSR was compared against GenBank database using BLASTN. Nine sequences, only from the dinucleotide library, were identical to previously published sequences, which already had primer pairs. These sequences were removed from this study.

Dinucleotide motifs have been reported as the most abundant type of microsatellite in plant genomes [17]. Recent studies relating to expressed sequence tags revealed that trinucleotide motifs are the most abundant motifs in ESTs in many plants, such as sugarcane [18], barley [19], grapes [20], rice [21], wheat [22] and citrus [23], whereas in other plants dinucleotide motifs are the most abundant in ESTs, such as kiwi [24], coffee [25] and apricot and peach [26] In rubber tree, Feng and co-workers analyzed all of the ESTs in NCBI database in search for microsatellites. They found that dinucleotide motifs were the most abundant and were three times more abundant than trinucleotides [6]. The low efficiency of the trinucleotide enrichment in our study could result from the low frequency of trinucleotide motifs in the rubber tree genome.

\section{Polymorphism analysis and cross-species transferability}

In total, 153 specific primer pairs were designed. A total of 119 primer pairs produced good amplification products (Additional file 1: Table S1) and 90 of these products were polymorphic among a set of 9 rubber clones indicated in Table 2.

Table 1 Number of sequences and SSRs of each type in each library

\begin{tabular}{lll}
\hline & Dinucleotide-enriched library & Trinucleotide-enriched library \\
\hline Number of sequences & 576 & 288 \\
Number of sequences with SSRs & 291 & 62 \\
Total number of SSRs & 359 & 70 \\
dinucleotide & 324 & 13 \\
trinucleotide & 12 & 45 \\
tetranucleotide & 20 & 9 \\
pentanucleotide & 3 & 3 \\
\hline
\end{tabular}


Table 2 Genotypes of $\boldsymbol{H}$. brasiliensis and six species of the genus Hevea used for characterization and transferability

\begin{tabular}{|c|c|c|c|}
\hline \multicolumn{3}{|c|}{ Genotypes $H$. brasiliensis } & \multirow{2}{*}{$\begin{array}{l}\text { Other species of Hevea } \\
\text { H. guianensis }\end{array}$} \\
\hline RRIM 600 & PB 311 & IRCA 209 & \\
\hline RRIM 606 & PB 346 & IRCA 230 & H. rigidifolia \\
\hline RRIM $701^{*}$ & PB $260^{*}$ & IRCA 707 & H. nitida \\
\hline RRIM 729 & PB $217^{*}$ & IRCA 1159 & H. pauciflora -(112 CNSG) \\
\hline RRIM 728 & PC 140 & GT $1^{*}$ & H. pauciflora -(116 CNSG) \\
\hline RRIM 805 & RRIC 100 & PR255 & H. benthamiana \\
\hline RRIM 809 & IAC 306 & $\mathrm{RO} 38^{*}$ & H. camargoana \\
\hline RRIM 913 & IAC 307 & Fx 4098 & \\
\hline RRIM 915 & IAC 309 & CMB $104^{*}$ & \\
\hline RRIM 937 & IAC 313 & CMB $114^{*}$ & \\
\hline RRII 105 & IAC 318 & & \\
\hline PB 233 & IAC 500 & & \\
\hline PB $235^{*}$ & IRCA 27 & & \\
\hline
\end{tabular}

*: genotypes used to characterize all of the SSRs markers developed.

The observed and expected heterozygosities ranged from 0.1111 to 1 and 0.1111 to 0.9150 , respectively, and the PIC values ranged between 0.0994 and 0.8496 . The mean number of alleles was 4.46 (2-9 alleles).

Of the 90 polymorphic markers we chose 46 SSRs for characterization among a set of 36 genotypes of $\mathrm{H}$. brasiliensis (Table 2). The PIC values of these markers ranged from 0.097 to 0.8339 , and the observed and expected heterozygosities ranged from 0.0909 to 0.9167 and 0.1387 to 0.8629 , respectively. The mean number of alleles was 6.4 (2-17 alleles) (Table 3$)$.

Six other species from the genus Hevea (H. guianensis, $H$. rigidifolia, $H$. nitida, $H$. pauciflora, $H$. benthamiana and $H$. camargoana) being two different genotypes of $H$. pauciflora, were used to evaluate the transferability of the markers (Table 2). All loci were tested under the same PCR conditions used for $H$. brasiliensis.

Of the 46 loci tested, 40 (87\%) were amplified for $H$. guianensis and H. pauciflora- (112CNSG), 39 (85\%) were amplified for $H$. camargoana, $H$. nitida and $H$. pauciflora-(116CNSG) and 38 (82\%) were amplified for H. benthamiana (Table 4).

For most of the SSR loci, which cross-species amplification were tested, the number of alleles found in the $H$. brasiliensis genotypes in conjunction with the tested species (from 2 to 21, with a mean number of 9.5) was larger when the same loci were analyzed in $H$. brasiliensis alone (Table 3) which means that other species revealed some novel alleles.

Three primers pairs, HB54, HB62 and HB69, did not produce amplification products for the six other species tested, whereas 27 loci were amplified for all species (Table 4).

Saha and co-workers first observed SSR crossamplification in $H$. benthamiana and H. spruceana [27].
Table $\mathbf{3}$ Characterization of the $\mathbf{4 6}$ polymorphic SSR markers

\begin{tabular}{|c|c|c|c|c|c|c|}
\hline Primer & $\frac{N A}{A}$ & $\begin{array}{l}\text { size } \\
\text { range } \\
\text { (bp) }\end{array}$ & $\mathrm{H}_{\mathrm{e}}$ & $\mathrm{H}_{\mathrm{o}}$ & PIC & $\frac{N A}{B}$ \\
\hline HB 31 & 6 & $182-173$ & 0.753 & 0.6875 & 0.7001 & 12 \\
\hline HB 32 & 6 & $256-238$ & 0.6057 & 0.3243 & 0.524 & 12 \\
\hline HB 33 & 9 & 188-171 & 0.6808 & 0.4 & 0.6388 & 10 \\
\hline HB 35 & 3 & 159-156 & 0.3882 & 0.4054 & 0.3226 & 5 \\
\hline HB 36 & 7 & $239-217$ & 0.6279 & 0.6111 & 0.557 & 16 \\
\hline HB 37 & 3 & $161-154$ & 0.6133 & 0.3235 & 0.5325 & 3 \\
\hline HB 41 & 6 & $141-173$ & 0.4855 & 0.3611 & 0.459 & 8 \\
\hline HB 42 & 7 & $203-216$ & 0.5313 & 0.5833 & 0.4954 & 10 \\
\hline HB 43 & 10 & 219-265 & 0.7531 & 0.5405 & 0.7133 & 15 \\
\hline HB 45 & 17 & $155-238$ & 0.856 & 0.8333 & 0.8273 & 21 \\
\hline HB 47 & 8 & $152-201$ & 0.6311 & 0.4722 & 0.566 & 14 \\
\hline HB 50 & 3 & $196-210$ & 0.2289 & 0.1944 & 0.2124 & 8 \\
\hline HB 51 & 2 & $196-201$ & 0.4909 & 0.1515 & 0.3666 & 7 \\
\hline HB 53 & 8 & $204-223$ & 0.7871 & 0.7568 & 0.7439 & 13 \\
\hline HB 54 & 10 & $168-203$ & 0.6708 & 0.5294 & 0.6201 & 10 \\
\hline HB 55 & 9 & 168-192 & 0.8 & 0.4571 & 0.7645 & 10 \\
\hline HB 57 & 9 & $147-176$ & 0.7169 & 0.6471 & 0.6831 & 12 \\
\hline HB 60 & 5 & 148-161 & 0.3154 & 0.3514 & 0.2985 & 6 \\
\hline HB 61 & 6 & 150-172 & 0.7175 & 0.9167 & 0.6662 & 11 \\
\hline HB 62 & 5 & $122-112$ & 0.415 & 0.1081 & 0.3888 & 5 \\
\hline HB 63 & 8 & $198-236$ & 0.7553 & 0.5135 & 0.7082 & 15 \\
\hline HB 64 & 8 & 146-199 & 0.6221 & 0.4444 & 0.5914 & 12 \\
\hline HB 66 & 3 & $273-279$ & 0.2273 & 0.25 & 0.2085 & 4 \\
\hline HB 68 & 10 & 138-167 & 0.8058 & 0.8286 & 0.7636 & 14 \\
\hline HB 69 & 10 & $139-172$ & 0.6962 & 0.6471 & 0.6426 & 10 \\
\hline HB 70 & 5 & $155-167$ & 0.6928 & 0.8 & 0.6281 & 6 \\
\hline HB 71 & 2 & 186-188 & 0.1037 & 0.1081 & 0.097 & 2 \\
\hline HB 73 & 6 & $206-228$ & 0.7754 & 0.8056 & 0.729 & 8 \\
\hline HB 77 & 4 & $135-153$ & 0.1788 & 0.0811 & 0.1701 & 8 \\
\hline HB 78 & 8 & $186-215$ & 0.7996 & 0.8286 & 0.7605 & 10 \\
\hline HB 81 & 9 & $187-220$ & 0.7469 & 0.5333 & 0.6979 & 13 \\
\hline HB 82 & 4 & $175-168$ & 0.5572 & 0.6757 & 0.4489 & 8 \\
\hline HB 83 & 4 & 181-165 & 0.5271 & 0.7143 & 0.4631 & 4 \\
\hline HB 92 & 7 & $255-229$ & 0.773 & 0.7576 & 0.7246 & 7 \\
\hline HB 95 & 6 & $254-225$ & 0.5742 & 0.5946 & 0.4793 & 12 \\
\hline HB 98 & 3 & 190-180 & 0.2787 & 0.3143 & 0.2535 & 4 \\
\hline HB 100 & 10 & $250-214$ & 0.803 & 0.8649 & 0.7657 & 16 \\
\hline HB 101 & 2 & $142-132$ & 0.2166 & 0.2432 & 0.1908 & 4 \\
\hline HB 102 & 4 & 198-157 & 0.2714 & 0.2973 & 0.2568 & 10 \\
\hline HB 103 & 2 & 164-161 & 0.1037 & 0.1081 & 0.097 & 2 \\
\hline HB 104 & 5 & $173-154$ & 0.6711 & 0.375 & 0.6119 & 14 \\
\hline HB 105 & 13 & $258-176$ & 0.8629 & 0.9091 & 0.8339 & 21 \\
\hline HB 106 & 5 & $210-230$ & 0.5855 & 0.0909 & 0.4975 & 6 \\
\hline
\end{tabular}


Table 3 Characterization of the $\mathbf{4 6}$ polymorphic SSR markers (Continued)

\begin{tabular}{lllllll}
\hline HB 109 & 6 & $186-210$ & 0.1387 & 0.1143 & 0.135 & 7 \\
HB 110 & 9 & $273-256$ & 0.8322 & 0.6667 & 0.7981 & 11 \\
HB 117 & 8 & $152-190$ & 0.8052 & 0.7222 & 0.7643 & 12 \\
\hline
\end{tabular}

$\mathrm{NA} / \mathrm{A}$, number of alleles in the $36 \mathrm{H}$. brasiliensis clones; NA/B, the total number of alleles in the $36 \mathrm{H}$. brasiliensis clones and in the other Hevea species; bp product size range in base pairs; He, expected heterozygosity; Ho, observed heterozygosity; PIC, polymorphism information content.

Together with the cross-fertility potential, this high SSR transferability supports the consideration of the Hevea genus as a species complex with moderate differentiation among the species. These aspects appear to be favorable for genetic introgressions using other Hevea species to the rubber breeding population, which is mainly based on H. brasiliensis.

\section{Locus duplication}

Members of the Euphorbiaceae family have a basic number of chromosomes between 6 and 11; thus, any species with more than this number of chromosomes could be amphidiploid in origin [28,29]. Similar to cassava, plants in the genus Hevea have 36 chromosomes and behave as diploid. In these species, it has been assumed that $n=18$ and the basic number of chromosomes is $\mathrm{x}=9[30,31]$.

In different Hevea species, chromosomes mainly formed bivalents and tetravalents are rarely produced as a result of pairing between non-homologous chromosomes during prophase I and metaphase I of meiosis [31,32].

Moreover, cytogenetic studies revealed two distinct loci on two different chromosomes, bearing the same18S5.8 S-25 S rDNA sequence which may have arisen by the hybridization of two unknown diploid species $(n=9)$, thus suggesting a possible allotetraploid origin, however no potencial diploid ancestor has been described to date [29].

Locus duplication, as revealed by molecular markers, had been reported in $H$. brasiliensis 11] and $H$. guianensis, $H$. rigidifolia and $H$. pauciflora [15].

In $H$. brasiliensis, we observed locus duplication for the markers HB45 and HB109 for clones RRIM 701 and Fx4098, respectively. Cases of locus duplication were observed in all Hevea species tested, with the exception of $H$. rigidifolia. We also observed locus duplication of the HB36, HB68, HB100 and HB105 markers in H. nitida; HB68 and HB105 markers in H. benthamiana; HB101 and HB105 in H. guianensis. The marker HB105 exhibited one duplicated locus for $H$. pauciflora (112 CNSG), H. pauciflora (116 CNSG) and H. camargoana.

Although we have not been mapped the loci we cited as duplicated in the wild species, we observed more than 2 alleles (excluding the stutter bands) in the same base pair range compared with the other genotypes used for characterization (Figure 1). The presence of allele duplication, as determined by polyacrylamide gel electrophoresis suggests that the loci are duplicated for the species involved.

Although locus duplication had been described in $H$. brasiliensis, $H$. guianinsis, $H$. rigidifolia and $H$. pauciflora, this is the first report for $H$. benthamiana, $H$. camargoana and $H$. nitida.

\section{Conclusion}

Herein, we report the development of new SSR markers for $H$. brasiliensis, representing a powerful resource for genetic diversity studies and genetic breeding techniques, such as molecular genetic mapping, QTLs identification and MAS.

Due to observed high percentage of cross-amplification and the absence of reproductive barriers between the species within this genus, these markers may be important tools to monitor the genetic variability from other Hevea species into the current breeding programs.In addition, these SSR markers can be helpful for the identification of important agronomic characteristics in different Hevea species.

\section{Methods}

\section{Plant material and DNA extraction}

We used 36 genotypes of $H$. brasiliensis to characterize the SSRs (Table 2). These genotypes were kindly provided by the Agronomic Institute of Campinas (IAC) and Michelin Plantation (Brasil). We also used 6 other species of the genus Hevea (H. guianensis, H. rigidifolia, $H$. nitida, $H$. pauciflora, $H$. benthamiana and $H$. camargoana) that were kindly provided by the Brazilian Agricultural Research Corporation (EMBRAPA - Amazônia Ocidental) in Manaus, AM to test the transferability of the SSRs (Table 2). The genomic DNA samples were extracted from lyophilized leaf tissues using a modified CTAB method [33] and their quality and quantity were assessed using $1 \%$ agarose gel electrophoresis.

\section{Construction of microsatellite-enriched libraries and sequence analysis}

The microsatellite-enriched libraries for $H$. brasiliensis were constructed using the RRIM 600 clone according to the methodology described by Billote and co-workers [34]. The DNA samples were digested with AFAI and enriched using streptavidin magnetic-coated beads (Streptavidin MagneSphere Paramagnetic Particles, Promega, Madison, WI) and $(\mathrm{CT})_{8}$ and $(\mathrm{GT})_{8}$ biotinylated microsatellite probes for the dinucleotide-enriched library or $(\text { ATC })_{8}$ and $(\mathrm{CCT})_{8}$ for the trinucleotide-enriched library.

Selected DNA fragments were amplified by PCR and then cloned into the pGEM-T vector (Promega, Madison, WI). Competent XL1-blue Escherichia coli cells were transformed with the recombinant plasmids and 
Table 4 Cross-amplification of the 46 polymorphic SSRs markers among the other Hevea species

\begin{tabular}{|c|c|c|c|c|c|c|c|}
\hline Primer & H. guianensis & H. rigidifolia & H. benthamiana & H. camargoana & H. nitida & $\begin{array}{l}\text { H. pauciflora- } \\
\text { (112 CNSG) }\end{array}$ & $\begin{array}{l}\text { H. pauciflora- } \\
\text { (116CNSG) }\end{array}$ \\
\hline HB-31 & + & + & + & + & + & - & + \\
\hline HB-32 & + & + & + & + & + & + & + \\
\hline HB-33 & + & - & + & + & + & + & + \\
\hline HB-35 & + & + & + & + & + & + & + \\
\hline HB-36 & + & + & + & + & + & + & + \\
\hline HB-37 & + & - & - & + & - & - & - \\
\hline HB-41 & + & + & + & + & + & + & + \\
\hline HB-42 & + & + & + & - & - & + & - \\
\hline HB-43 & + & + & + & + & + & + & + \\
\hline HB-45 & + & + & + & + & + & + & + \\
\hline HB-47 & - & + & + & + & + & + & + \\
\hline $\mathrm{HB}-50$ & - & + & + & + & + & + & + \\
\hline HB-51 & + & + & + & + & + & + & - \\
\hline HB-53 & + & + & + & + & + & + & + \\
\hline HB-54 & - & - & - & - & - & - & - \\
\hline HB-55 & + & + & - & - & - & + & + \\
\hline HB-57 & + & + & + & + & + & + & + \\
\hline HB-60 & + & + & + & + & + & + & - \\
\hline HB-61 & + & + & + & + & + & + & + \\
\hline HB-62 & - & - & - & - & - & - & - \\
\hline HB-63 & + & + & + & + & + & + & + \\
\hline HB-64 & + & + & + & + & + & + & + \\
\hline HB-66 & + & + & + & + & + & + & + \\
\hline HB-68 & - & + & + & + & + & + & + \\
\hline HB-69 & - & - & - & - & - & - & - \\
\hline HB-70 & + & + & + & + & + & + & + \\
\hline HB-71 & + & + & + & + & + & + & + \\
\hline HB-73 & + & + & + & + & + & - & - \\
\hline HB-77 & + & + & + & + & + & + & + \\
\hline HB-78 & + & + & + & + & + & + & + \\
\hline HB-81 & + & - & + & + & + & + & + \\
\hline HB-82 & + & + & + & + & + & + & + \\
\hline HB-83 & + & + & + & + & + & + & + \\
\hline HB-92 & + & - & + & + & + & + & + \\
\hline HB-95 & + & + & + & + & + & + & + \\
\hline HB-98 & + & + & + & + & + & + & + \\
\hline HB-100 & + & + & + & + & + & + & + \\
\hline HB-101 & + & + & + & + & + & + & + \\
\hline HB-102 & + & + & + & + & + & + & + \\
\hline HB-103 & + & + & - & - & + & + & + \\
\hline HB-104 & + & + & + & + & + & + & + \\
\hline HB-105 & + & + & + & + & + & + & + \\
\hline HB-106 & + & - & + & - & - & + & + \\
\hline
\end{tabular}


Table 4 Cross-amplification of the 46 polymorphic SSRs markers among the other Hevea species (Continued)

\begin{tabular}{llllllll}
\hline $\mathrm{HB}-109$ & + & + & + & + & + & + & + \\
$\mathrm{HB}-110$ & + & + & + & + & + & + & + \\
$\mathrm{HB}-117$ & + & + & + & + & + & + & + \\
\hline
\end{tabular}

cultivated on agar medium containing ampicillin and $100 \mu \mathrm{g} / \mathrm{ml}$ of X-galactosidase. The clones containing the insert were sequenced using the Big Dye Terminator v3.1 Cycle Sequencing Kit (Applied Biosystems, Foster City, CA) and an automated ABI 377 sequencer (Applied Biosystems, Foster City, CA).

All the sequences obtained were aligned, edited and eliminated if redundant using SeqMan (DNASTAR, Madison, WI). The sequences were also evaluated using Microsat software (A. M. Risterucci, CIRAD, personal communication), which removes the adapters and verifies the presence of restriction sites.

The microsatellites were identified using a specific research tool, SSRIT - (Simple Sequence Repeat Identification Tool) [35]. As a criterion for the SSR selection, the sequences that showed at least five dinucleotide repeats; four trinucleotide repeats; and three tetra-, penta- and hexanucleotide repeats were selected. Primers complementary to the sequences flanking the microsatellites were designed using Primer Select Program (DNAStar, Madison, WI) and Primer 3 [36]. To eliminate possible redundancies with the published SSRs, each sequence containing microsatellite was compared against the GenBank database using BLASTN. The redundant sequences which already had primer pairs published were eliminated.

\section{PCR amplification}

The microsatellite fragments were PCR amplified in a $15 \mu \mathrm{l}$ reaction containing $25 \mathrm{ng}$ template DNA, $0.5 \mu \mathrm{M}$ each primer, $100 \mu \mathrm{M}$ each $\mathrm{dNTP}, 1.5 \mathrm{mM} \mathrm{MgCl}_{2}$, $20 \mathrm{mM}$ Tris- $\mathrm{HCl}, 50 \mathrm{mM} \mathrm{KCl}$ and $0.5 \mathrm{U}$ Taq DNA Polymerase. The PCR amplifications were performed with the following four programs: (1) initial denaturation at $94^{\circ} \mathrm{C}$ for $4 \mathrm{~min}, 30$ amplification cycles $\left(1 \mathrm{~min}\right.$ at $94^{\circ} \mathrm{C}$, $45 \mathrm{~s}$ at the specific annealing temperature and $1 \mathrm{~min}$ at $72^{\circ} \mathrm{C}$ ), and a final extension at $72^{\circ} \mathrm{C}$ for $10 \mathrm{~min}$; (2) TD-1, initial denaturation for $3 \mathrm{~min}$ at $94^{\circ} \mathrm{C}, 10$ amplification cycles with a $0.5^{\circ} \mathrm{C}$ decrease in annealing temperature per cycle starting at $55^{\circ} \mathrm{C}$ or $60^{\circ} \mathrm{C}\left(94^{\circ} \mathrm{C}\right.$ for $1 \mathrm{~min}, 60^{\circ} \mathrm{C}$ or $55^{\circ} \mathrm{C}$ for $30 \mathrm{~s}$, and $72^{\circ} \mathrm{C}$ for $1 \mathrm{~min} 15 \mathrm{~s}$ ); followed by 20 cycles with annealing at $50^{\circ} \mathrm{C}\left(94^{\circ} \mathrm{C}\right.$ for $1 \mathrm{~min}, 50^{\circ} \mathrm{C}$ for $30 \mathrm{~s}$ and $72^{\circ} \mathrm{C}$ for $30 \mathrm{~s}$ ) and a final elongation step at $72^{\circ}$ C for $10 \mathrm{~min}$; (3) TD-2, previously described by Le Guen and co-workers [10]; and (4) TD-3, initial denaturation at $94^{\circ} \mathrm{C}$ for $2 \mathrm{~min}, 2 \times 10$ cycles with a $1^{\circ} \mathrm{C}$ decrease in annealing temperature per cycle from $65^{\circ} \mathrm{C}$ to $55^{\circ} \mathrm{C}\left(94^{\circ} \mathrm{C}\right.$ for $1 \mathrm{~min}, 65^{\circ} \mathrm{C}$ for $1 \mathrm{~min}$ and $72^{\circ} \mathrm{C}$ for $1 \mathrm{~min}$ ), followed by 18 cycles at $55^{\circ} \mathrm{C}\left(94^{\circ} \mathrm{C}\right.$ for $1 \mathrm{~min}, 55^{\circ} \mathrm{C}$ for $1 \mathrm{~min}$ and $72^{\circ} \mathrm{C}$ for $2 \mathrm{~min}$ ), and a final elongation step at $72^{\circ} \mathrm{C}$ for $5 \mathrm{~min}$.

The amplification products were resolved by electrophoresis through 3\% agarose gels prior to vertical electrophoresis using 6\% denaturing polyacrylamide gels and were subsequently silver stained [37]. The product sizes were determined by comparison with a 10 bp DNA ladder (Invitrogen, Carlsbad, CA).

\section{Analysis}

The allelic polymorphic information content of each SSR was calculated using the formula $P I C=1-\sum_{i=1}^{n} p_{i}^{2}-$ $\sum_{i=1}^{n} \sum_{j=i+1}^{n} 2 p_{i}^{2} p_{j}^{2}$, where $\mathrm{n}$ is the number of alleles of the marker among the set of genotypes used for characterizing the SSR polymorphism, and pi and pj are the frequencies of alleles $i$ and $j$. The observed and expected heterozygosities were calculated using the TFPGA program [38].

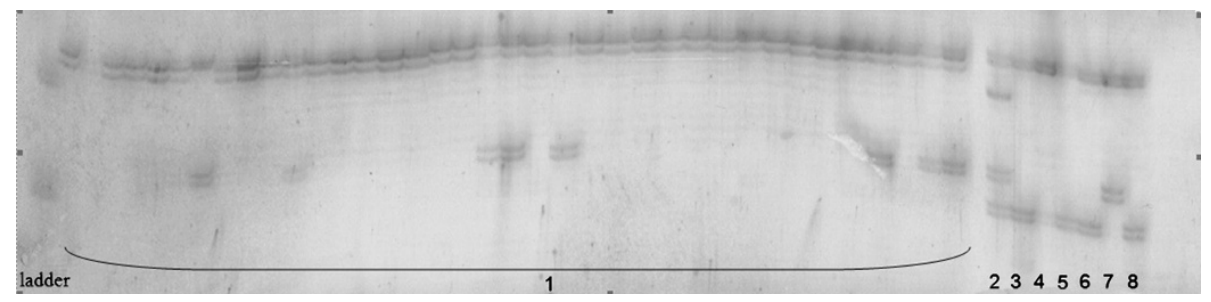

Figure 1 A $6 \%$ denaturing silver-stained polyacrilamyde gel for the characterization of the HB101 marker. PCR product for the HB101 marker in the 36 genotypes of $\mathrm{H}$. brasiliensis and the 6 other species of Hevea which more than 2 alleles can be observed for $\mathrm{H}$. guianensis.

(1) H. brasiliensis; (2) H. guianensis; (3) H. rigidifolia; (4) H. nitida; (5) H. pauciflora - (112 CNSG); (6) H. pauciflora - (116 CNSG); (7) H. benthamiana; and (8) H. camargoana. 


\section{Additional file}

Additional file 1: Table S1. Characterization of the developed SSR markers. The table presents the 119 SSR markers developed for $H$. brasiliensis, including the primers sequence, annealing temperature, number of alleles, expected size in base pair, allelic range, observed and expected heterozigosity and polymorphism information content. The nine accession indicated in Table 1 were used for the SSR characterization.

\section{Competing interests}

The authors declare that they have no competing interests.

\section{Acknowledgements}

The authors thank the Brazilian Agricultural Research Corporation (EMBRAPA Amazônia Ocidental) and the Agronomic Institute for donating the analyzed Hevea germplasm. This work was supported by grants from Fundação de Amparo à Pesquisa do Estado de São Paulo (FAPESP, proc. 2007/50562-4). CCM and FIS received undergraduate scholarships (2008/55974 and 2009/51757-9) and, LMS and CCM received graduate scholarships (2007/50392-1 and 2011/ 50188-0) from FAPESP. APS and PSG are recipient of a research fellowship from Conselho Nacional de Desenvolvimento Científico e Tecnológico (CNPq).

\section{Author details}

${ }^{1}$ Centro de Biologia Molecular e Engenharia Genética (CBMEG) -

Universidade Estadual de Campinas (UNICAMP), Cidade Universitária Zeferino Vaz, CP 6010, CEP 13083-970, Campinas, SP, Brazil. ' Instituto Agronômico de Campinas (IAC), CP 28, Campinas SP, CEP 13012-970, Brazil. ³Departamento de Biologia Vegetal, Instituto de Biologia, Universidade Estadual de Campinas (UNICAMP), Cidade Universitária Zeferino Vaz, CP 6109, CEP 13083-970, Campinas, SP, Brazil.

\section{Authors' contributions}

CCM and FIS developed the microsatellite-enriched libraries, performed the computational microsatellite identification, designed the flanking primers and performed the microsatellite marker validation. CCM performed the statistical analysis and drafted the manuscript. LMS participated in the design and implementation of the study and the microsatellite identification. APS and PSG conceived the study and participated in its design and coordination. APS helped to draft the manuscript. All of the authors read and approved the final manuscript.

Received: 6 April 2012 Accepted: 15 June 2012

Published: 25 June 2012

\section{References}

1. Pires JM, Secco RS, Gomes Jl: Taxonomia e fitogeografia das seringueiras Hevea spp. Belém: Embrapa Amazônia Oriental; 2002:103.

2. Gonçalves $P$, Cardoso M, Ortolani AA: Origem, variabilidade e domesticação da Hevea; uma revisão. Pesquisa agropecuária brasileira 1990, 25(2):135-156.

3. Clément-Demange A, Priyadarshan PM, Thuy Hoa T, Venkatachalam P: Hevea Rubber Breeding and Genetics. In Plant Breeding Reviews. Volume 29th edition. Edited by Janick J. New Jersey: John Wiley \& Sons, Inc; 2007:ch 4.

4. Cornish $\mathrm{K}$ : Similarities and differences in rubber biochemistry among plant species. Phytochem 2001, 57:1123-1134.

5. Webster CC, Baulkwill WJ: Rubber Longman edn. Longman Singapore Publishers Ltd; 1989.

6. Feng SP, Li WG, Huang HS, Wang JY, Wu YT: Development, characterization and cross-species/genera transferability of EST-SSR markers for rubber tree (Hevea brasiliensis). Mol Breeding 2009, 23:85-97.

7. Kalia RK, Rai MK, Kalia S, Singh R, Dhawan AK: Microsatellite markers: an overview of the recent progress in plants. Euphytica 2011, 177:309-334.

8. Chevallier MH: Genetic variability of Hevea brasiliensis germplasm using isozyme markers. J Nat Rubber Res 1988, 3:42-53.

9. Besse P, Seguin M, Lebrun P, Chevallier MH, Nicolas D, Lanaud C: Genetic diversity among wild and cultivated populations of Hevea brasiliensis assessed by nuclear RFLP analysis. Theor Appl Genet 1994, 88:199-207.

10. Le Guen V, Gay C, Xiong TC, Souza LM, Rodier-Goud M, Seguin M: Development and characterization of 296 new polymorphic microsatellite markers for rubber tree (Hevea brasiliensis). Plant Breeding 2011, 130:294-296
11. Lespinasse D, Rodier-Goud M, Grivet L, Leconte A, Legnate H, Seguin M: A saturated genetic linkage map of rubber tree (Hevea spp.) based on RFLP, AFLP, microsatellite, and isozyme markers. Theor Appl Genet 2000, 100:127-138.

12. Le Guen V, Garcia D, Mattos CRR, Doaré F, Lespinasse D, Seguin M: Bypassing of a polygenic Microcyclus ulei resistance in rubber tree, analyzed by QTL detection. New Phytologist 2007, 173:335-345.

13. Le Guen V, Lespinasse D, Oliver G, Rodier-Goud M, Pinard F, Seguin M: Molecular mapping of genes conferring field resistance to South American Leaf Blight (Microcyclus ulei) in rubber tree. Theor Appl Genet 2003, 108:160-167.

14. Lespinasse D, Grivet L, Troispoux V, Rodier-Goud M, Pinard F, Seguin M: Identification of QTLs involved in the resistance to South American leaf blight (Microcyclus ulei) in the rubber tree. Theor Appl Genet 2000, 100:975-984.

15. Souza LM, Mantello CC, Santos MO, Gonçalves PO, Souza AP: Microsatellites from rubber tree (Hevea brasiliensis) for genetic diversity analysis and cross amplification in six Hevea wild species. Cons Genet Res 2009, 1:75-79.

16. Yu F, Wang BH, Feng SP, Wang JY, Li WG, Wu YT: Development, characterization, and cross-species/genera transferability of SSR markers for rubber tree (Hevea brasiliensis). Plant Cell Rep 2010, 30:335-344.

17. Morgante M, Hanafey M, Powell W: Microsatellites are preferentially associated with nonrepetitive DNA in plant genomes. Nat Genet 2002, 30:194-200

18. Marconi TG, Costa EA, Miranda HRCAN, Mancini MC, Cardoso-Silva CB, Oliveira KM, Pinto LR, Mollinari M, Garcia AAF, Souza AP: Functional markers for gene mapping and gnetic diversity studies in sugarcane. BMC Research Notes 2011, 4:264.

19. Scott KD, Eggler P, Seaton G, Rossetto M, Ablett EM, Lee LS, Henry RJ: Analysis of SSRs derived from grape ESTs. Theor Appl Genet 2000, 100:723-726.

20. Thiel T, Michalek W, Varshney RK, Graner A: Exploiting EST databases for the development and characterization of genederived SSR-markers in barley (Hordeum vulgare L.). Theor App/ Genet 2003, 106:411-422.

21. Han Z, Wang C, Song X, Guo W, Gou J, Li C, Chen X, Zhang T: Characteristics, development and mapping of Gossypium hirsutum derived EST-SSRs in allotetraploid cotton. Theor App/ Genet 2006, 112:430-439.

22. La Rota M, Kantety RV, Yu JK, Sorrells ME: Nonrandom distribution and frequencies of genomic and EST-derived microsatellite markers in rice, wheat, and barley. BMC Genomics 2005, 6:2.

23. Chen C, Zhou P, Choi YA, Huang S, Gmitter FG Jr: Mining and characterizing microsatellites from citrus ESTs. Theor App/ Genet 2006, 112:1248-1257.

24. Fraser LG, Harvey CF, Crowhurst RN, De Silva HN: EST-derived microsatellites from Actinidia species and their potential for mapping. Theor Appl Genet 2004, 108:1010-1016.

25. Aggarwal RK, Hendre PS, Varshney RK, Bhat PR, Krishnakumar V, Singh L: Identification, characterization and utilization of EST-derived genic microsatellite markers for genome analyses of coffee and related species. Theor Appl Genet 2007, 114:359-372.

26. Jung S, Albert A, Jesudurai C, Tomkins J, Main D: Frequency, type, distribution and annotation of simple sequence repeats in Rosaceae ESTs. Funct Integr Genomics 2005, 5:136-143.

27. Saha T, Roy CB, Nazeer MA: Microsatellite variability and its use in the characterization of cultivated clones of Hevea brasiliensis. Plant Breeding 2005, 124:86-92.

28. Perry AB: Chromosome Number and Phylogenetic Relationships in the Euphorbiaceae. Am J Bot 1943, 30:527-543.

29. Leitch AR, Lim KY, Leitch IJ, O'Neill M, Chye M, Low F: Molecular cytogenetic studies in rubber, Hevea brasiliensis Muell. Arg. (Euphorbiaceae). Genome 1998, 41:464-467.

30. Majumder SK: Chromosome studies of some species of Hevea. J. Rubber Res. Inst. Malays 1964, 18:269-273.

31. Ong SN: Chromosome morphology at pachytene stage in Hevea brasiliensis: a preliminary report. In Proceedings of the International Rubber Conference. Edited by Sripathi B. Kuala Lumpur: Rubber Research Institue of Malaysia; 1975:3-12.

32. Bouharmont J: Recherches taxonomiques et caryologiques chez quelques espèces du genre Hevea. In Série Scientifique. Volume 85th edition. Edited by INEAC:; 1960:64.

33. Doyle JJ, Doyle $\mathrm{J}$ : A rapid DNA isolation procedure for small quantities of fresh leaf tissue. Phytochem Bull 1987, 19:11-15. 
34. Billotte N, Lagoda P, Risterucci AM, Baurens FC: Microsatellite-enriched libraries: applied methodology for the development of SSR markers in tropical crops. Fruits 1999, 54:277-288.

35. Temnykh S, Declerck G, Lukashova A, Lipovich L, Cartinhour S, McCouch S: 2001. Computational and experimental analysis of microsatellites in rice (Oryza sativa L.): Frequency, length variation, transposon associations, and genetic marker potential. Genome Res 2001, 11:1441-1452.

36. Untergasser A, Nijveen H, Rao X, Bisseling T, Geurts R, Leunissen JAM: Primer3Plus, an enhanced web interface to Primer3. Nucleic Acids Res 2007, 35:W 71-W74

37. Creste S, Tulmann-Neto A, Figueira A: Detection of single repeat polymorphisms in denaturing polyacrilamide sequencing gels by silver staining. Plant Mol Biol Rep 2001, 19:229-306.

38. Miller MP: Tools for population genetic analysis (TFPGA) 1.3: A Windows program for the analysis of allozyme and molecular population genetic data. Computer Software distributed by the author; 1997.

doi:10.1186/1756-0500-5-329

Cite this article as: Mantello et al: Microsatellite marker development for the rubber tree (Hevea brasiliensis): characterization and crossamplification in wild Hevea species. BMC Research Notes 2012 5:329.

\section{Submit your next manuscript to BioMed Central and take full advantage of:}

- Convenient online submission

- Thorough peer review

- No space constraints or color figure charges

- Immediate publication on acceptance

- Inclusion in PubMed, CAS, Scopus and Google Scholar

- Research which is freely available for redistribution 